\title{
Understanding Informal Actors of Plastic Waste Recycling in Semarang City
}

\author{
Budi Prasetyo Samadikun ${ }^{*}$, Arya Rezagama1, Bimastyaji Surya Ramadan ${ }^{1}$, Pertiwi \\ Andarani ${ }^{1}$, dan Erina Dwi Rumanti ${ }^{1}$
}

${ }^{1}$ Department of Environmental Engineering, Faculty of Engineering, Universitas Diponegoro, Semarang- 50275, Indonesia; e-mail: budisamadikun@gmail.com

\begin{abstract}
ABSTRAK
Kegiatan daur ulang sampah di Kota Semarang dapat dilakukan dengan cukup baik berkat campur tangan dari sektor informal. Sayangnya, kegiatan pengelolaan sampah formal tidak mempertimbangkan nilai pemulihan sampah. Penelitian ini bertujuan untuk mengidentifikasi aliran sampah plastik di sektor informal di Kota Semarang. Peneliti menggunakan wawancara mendalam untuk mengumpulkan data. Ada 46 agen daur ulang, termasuk 5 pemulung, 17 pengepul 20 perusahaan skala kecil, 3 perusahaan skala besar, dan 1 perantara (pabrik penggilingan plastik) yang telah diwawancarai. Data timbulan sampah dan actor informal didapatkan dari Badan Lingkungan Hidup Kota Semarang. Hasil penelitian menunjukkan bahwa jumlah sampah plastik yang dihasilkan oleh masing-masing agen daur ulang diperkirakan 23,98 kg/ hari di tingkat pemulung, 54,74 kg/ hari di tingkat pengepul, 347,48 kg / hari di tingkat perusahaan skala kecil, 1.735,3 kg/hari di tingkat perusahaan skala besar, dan $2.160 \mathrm{~kg} / \mathrm{hari}$ di tingkat perantara. Produsen bijih plastik daur ulang berlokasi di luar Kota Semarang, sedangkan bank sampah berbasis masyarakat sebagai bagian dari aktor informal pengelolaan sampah berbasis masyarakat tidak mencari keuntungan sehingga tidak dibahas secara mendalam di penelitian ini.
\end{abstract}

Kata kunci: Sampah plastik, Aliran sampah, Agen daur ulang

\begin{abstract}
Waste recycling activities in Semarang City can be conducted quite well due to the interference of the informal sector. Unfortunately, the formal waste management activities do not consider the utilization of waste recovery value. This study aims to identify the flow of plastic waste in the informal sector in Semarang City. We used in-depth interviews to collect data. There are 46 recycling agents, including 5 scavengers, 17 scrap dealers, 20 small-scale enterprises, 3 large-scale enterprises, and 1 intermediate (plastic grinding mill) that has been interviewed. Waste generation and informal actors contact are gathered from The Environment Agency of Semarang City. The results showed that the amount of plastic waste generated by each recycling agent was estimated at $23.98 \mathrm{~kg} /$ day at the scavenger level, $54.74 \mathrm{~kg} /$ day at the scrap dealer level, $347.48 \mathrm{~kg} / \mathrm{day}$ at the small-scale enterprise level, $1,735.3 \mathrm{~kg} /$ day days at large-scale enterprise level, and 2,160 kg/day at the level of plastic waste intermediates. Recycled plastic ore producers are located outside Semarang City, whereas the community-based waste bank is part of community based solid waste management that is not looking for profit is not discussed in depth in this study.
\end{abstract}

Keywords: Plastic waste, Waste flow, Recycling agent

Citation: Samadikun, B.P., Rezagama, A., Ramadan, B.S., Andarani, P., Rumanti, E.D. (2020). Understanding Informal Factors of Plastic Wast Recycling in Semarang City. Jurnal Ilmu Lingkungan, 18(1), 162-170, doi:10.14710/jil.18.1.162-170

\section{Introduction}

The municipal solid waste generated by Semarang city residents reaches $835,000 \mathrm{~kg}$ per day, where less than $16.28 \%$ of them is a plastic waste (Budihardjo and Wahyuningrum, 2018; Pertiwi et al., 2018). Most people in Semarang City dispose of waste without segregation. The solid waste is collected at the transfer depo then transported to the landfill site using dump trucks and arm-roll trucks. Waste collection from house to house done by the informal sector, with a levy that varies depending on each location. Residents must put their waste in front of the house to be taken by officers appointed by the neighborhood association. The officer then delivers the waste to the waste collection site that has been provided by the government. Waste collection is carried out by using a pedicab, or a part of it is directly transported by truck (Yuliastuti and Saraswati, 2014).

Plastic waste handling is often done by recycling, burning, and burial. Burning plastic waste produces toxic substances that are harmful to living things. The poisonous substances mentioned before, such as polychlorinated dibenzo-p-dioxins and polychlorinated dibenzofurans (Lemieux et al., 2000). While burial is ineffective because plastics are likely to persist due to their durability, hence, rapidly 
accumulating in the environment (Thompson, 2006). Reusing waste material by recycling is one of the effective ways to avoid environmental pollution and reduce the volume of its generation in landfills (Filho et al., 2019).

The absence of source segregation is the cause of the ineffectiveness of plastic waste recycling activities which lead to the high volume of plastic waste transported to landfill (Kinobe et al., 2015). This activity has led to the emergence of several alternative plastic waste management, including recycling, combustion, and reuse (Govindan et al., 2015). Based on the results of experts' research, recycling activities can reduce the total amount of waste accumulated in the landfill and is one of the efforts to conserve natural resources (Xu et al., 2017). Recycling activities by the informal sector indeed contributes to saving raw material resources, demand for landfill area, save energy in producing various consumer products, and increase job opportunities in the waste recycling industry (Batool et al., 2008; Gregory and Kirchain, 2008; Nahman, 2010).

Tong et al. (2018) mentioned that waste management in urban areas usually includes the formal sector and the informal sector. In Indonesia, the formal sector in waste management is carried out by local governments, including self-managed or delegated to local companies. Meanwhile, the informal sector consists of individuals, groups, or small businesses that are not incorporated or do not have standard rules in carrying out their operations. Waste segregation is usually done by the informal sector, such as scavengers, scrap dealers, and enterprises. Recycling actors in the informal industry considered as having economic value by recycling ( $\mathrm{Li}$ and Tee, 2012).

Waste reduction in Semarang City has been carried out by a small number of residents who manage their waste by sorting and selling to waste banks or scrap dealers, and making compost from their organic waste (Lestari and Trihadiningrum, 2019). The informal sector considered in this study includes scavengers, scrap dealers, small-scale enterprises, large-scale enterprises, and grinders that play a significant role in the reduction of plastic waste in a city (Sasaki et al., 2014). Small-scale enterprise is the first level intermediaries who will distribute large quantities of recyclable materials per composition to the next intermediaries, namely grinders or factories. In practice, small-scale enterprises do not always sell waste to large-scale enterprises but can directly sell scrap to plastic grinders or factories.

This study aims to understand the current flow of plastic waste and the actors who play a role in the efforts to recycle plastic waste. Research is limited by actors who stand independently and work professionally to take advantage of the benefits of plastic waste recycling. Therefore, the waste bank, as an embodiment of community based solid waste management, that is not concerned with personal profit, is not included in the scope of this study. Currently, there is no peer-reviewed article regarding the identification of waste management in Semarang City, especially regarding plastic waste that has never been done before. Thus, this research is expected to be a baseline study to create a model/design of an efficient and effective plastic waste flow scheme.

\section{Method}

\subsection{Data collection}

This research was conducted using survey methods and in-depth interviews with informal recycling practitioners in the city of Semarang. A database of waste recyclers was obtained from the Environmental Agency of Semarang City, which was then surveyed directly to ascertain the location and whereabouts of the recyclers. Recycling agents surveyed include scavengers, scrap dealers, smallscale enterprises, big dealers, and the intermediate (grinding mill). The sampling technique used was random sampling because we considered the uniformity of the characteristics of the informal actors in plastic waste recycling activities. The questions in the questionnaire were arranged systematically to make it easier for respondents to answer. This research questionnaire uses open questions to gain more data from informal actors. Details of the questions and the number of respondents surveyed are presented in Table 1.

Table 1. Targeted Interviewees and Information

\begin{tabular}{|c|c|c|c|}
\hline No. & $\begin{array}{c}\text { Targeted } \\
\text { interviewees }\end{array}$ & $\begin{array}{l}\text { Sample } \\
\text { number }\end{array}$ & Obtained Information \\
\hline 1. & Scavengers & 5 & $\begin{array}{l}\text { 1. Respondent's identity } \\
\text { 2. Plastic waste }\end{array}$ \\
\hline 2. & Scrap dealers & 17 & collection activities \\
\hline 3. & $\begin{array}{l}\text { Small-scale } \\
\text { enterprises }\end{array}$ & 20 & $\begin{array}{l}\text { Operating } \\
\text { location }\end{array}$ \\
\hline 4. & $\begin{array}{l}\text { Large-scale } \\
\text { enterprises }\end{array}$ & 3 & $\begin{array}{l}\text { - Types of waste } \\
\text { traded }\end{array}$ \\
\hline 5. & $\begin{array}{l}\text { Intermediate } \\
\text { (grinding } \\
\text { mill) }\end{array}$ & 1 & $\begin{array}{l}\text { The amount of } \\
\text { plastic waste } \\
\text { obtained (in kg) }\end{array}$ \\
\hline
\end{tabular}

\subsection{Data analysis}

Material flow analysis was used to identify the reverse logistics system for managing plastic waste in Semarang city. The mass of waste and the composition of plastic waste managed by each recycling agent were identified to find out the types of plastic waste that could be sold based on the classification set by the recycling actors. Data obtained from the survey, including measured weight data of plastic waste, were processed using Microsoft Excel $®$ and then calculated the total value and the average value for each recycling agent.

\section{Results and Discussion \\ 3.1. The existing condition of plastic waste recycling activities in Semarang City}


Plastic recycling activities were studied outside the formal system of waste management in Semarang City. Plastic waste is still managed individually through the informal sector. Residents put their solid waste in the trash bin or plastic bags in front of their homes or at designated waste collection points. The average waste collection is done twice a week. As can be estimated that the waste collected reaches 10 tons per day. The local Environmental Agency does not provide officers to sort waste at the time of transport or disposal at the transfer depo because the solid waste is not segregated from the source (such as household, market, school, restaurants, and other public facilities).

Developing countries like Indonesia and Thailand use the same waste management technique, which is local government carried out waste management service from waste collection point to landfill. At the waste collection point, the scavengers sort the waste among valuable (recyclable) and nonvaluable waste. Such a system has weaknesses such as the generation of an accumulation point of waste on the roadside. Also, transporting solid waste by dump truck allows the waste to fall on the streets so that it may pollute the environment (Yukalang et al., 2017). Recycling is informally spread across various districts and managed by individuals and enterprises.

Scrap dealers obtain their recyclables by buying them from the community. Then, selling them back to more prominent scrap dealers, small-scale enterprises, and large-scale enterprises. Large-scale enterprise is a recycler who receives and buys potential recyclables for resale to the intermediates, which will grind the plastic waste into small pieces (pellets). Scrap dealers are categorized as a recycling business that accepts plastic waste with a capacity of less than $100 \mathrm{~kg}$. A small-scale enterprise has a capacity between $100-1000 \mathrm{~kg}$ and large-scale enterprise more than $1000 \mathrm{~kg}$. The grinder is a recycler who processes certain types of plastic waste and converts them into chopped plastic or even plastic ores.

The plastic waste flow starts from scavengers (waste pickers) who sell recycled goods to scrap dealers and small-scale enterprises. Furthermore, the scrap dealers will sell the products to small-scale enterprises or large-scale enterprises. The large-scale enterprise is the last collector to sell recyclables to the grinding mill (intermediates) or directly to the recycling industry. Recycling business actors who can directly interact with household waste management actors are scavengers and scrap dealers. However, direct interaction may exist among household waste management actors. The relationship between waste banks with small-scale or large-scale enterprise are the examples. The large-scale enterprises generally only accept purchases with a minimum weight limit, but some receive it from the individual (household), scavengers, and scrap dealers. Therefore, the flow of plastic waste is not standardized, i.e., the scavengers or scrap dealers can directly sell plastic waste to the small-large enterprise. The plastic trash can later be processed into the same product type or as primary or secondary raw materials for a different kind of products. The scavengers may also be employed by small-scale enterprises. The scheme of plastic waste flow in Semarang city can be seen in Figure 1.

The collected recyclables are managed by the scrap dealers who cooperate with the small-scale enterprise. The sorting process is carried out to segregate the types of plastic waste and other waste, such as paper and metal. Plastics are separated based on standards such as AD / HD / LDPE, PEE, PP, screen printing, bucket, sack, and slop. The sorted plastic is then transported to scrap dealers for sale or to receive wages. waste is packaged and transported to a plastic processing industry to be used as a primary raw Waste in the small-scale enterprise is then collected until it reaches a minimum weight determined by the large-scale enterprise. After the tonnage of the waste is by the minimum weight, the material in the process of making plastic products. In a study conducted by Sasaki et al. (2014), scavengers could sell collected plastics without the initial sorting process by scrap dealers (Sasaki et al., 2014)

Based on the survey results, to build a recycling business, the higher the level of activity, the greater the networking required. The waste sector is now considered as one of the industries that are quite reliable because every day, the community generates waste, and most of this waste still has economic value. A recycling business does not require a large amount of capital, and the financial flow is quite fast. However, this waste collection activity requires adequate knowledge, especially regarding the standard types of waste that sometimes differ from one another.

\subsection{Composition and Weight of Plastic Waste}

The most significant contributor to waste generation in Semarang city is households with a total waste generation of about $716,143 \mathrm{~kg} /$ day and followed by markets with a generation amount of $11,610 \mathrm{~kg} /$ day, as a center for trade and socialization of the community in an area. Total waste generation in Semarang city is about $835,323 \mathrm{~kg} /$ day. The most significant contributor to organic waste is marketplace. Typical organic waste in urban areas is the remnants of fresh vegetables and fruits. Every day one market can generate organic waste of more than $500 \mathrm{~kg} /$ day (Aye and Widjaya, 2006). Plastic waste occupies the landfill. A landfill needs to deal with more than 1 ton of plastic waste. 


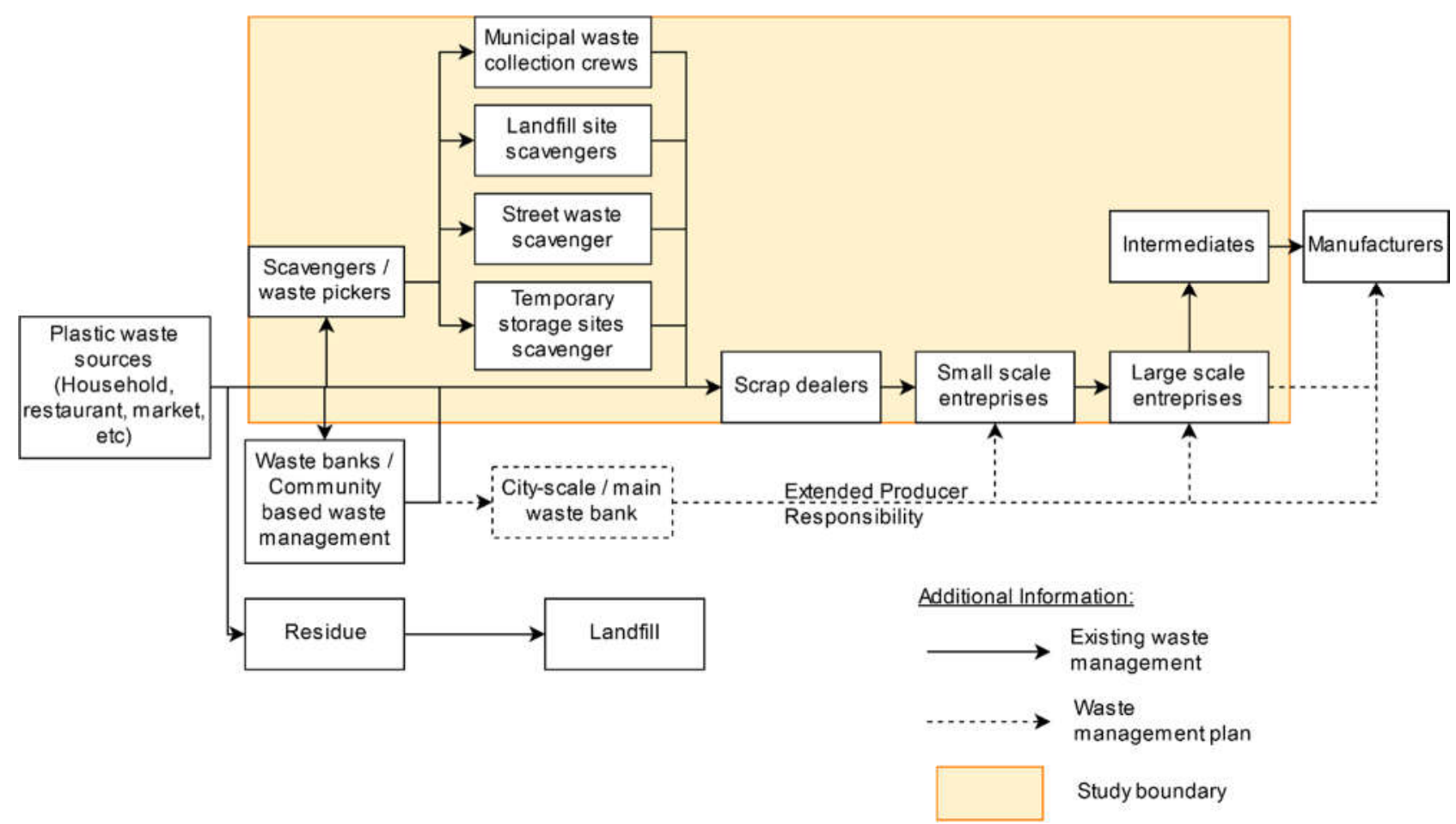

Figure 1. Schematic system of plastic waste flow in Semarang City

Meanwhile, the plastic waste that can be degraded naturally is only $4.36 \%$ of the total waste (Herewila et al., 2017). According to Chaerul et al. (2013), plastic waste that can be recycled in Bandung city is only $3.76 \%$ or 58.4 tonnes per day of the total waste. This condition occurs because only a few of the incoming waste could be managed by the informal sectors and the rest is only disposed of without being processed first (Aprilia et al., 2013). Optimizing the informal sector is essential to increase the amount of plastic recycling in Semarang City.

Table 2. Total Composition Percentages of Plastic Waste from Samples

\begin{tabular}{llcc}
\hline \hline $\begin{array}{c}\text { Recycle } \\
\text { Code }\end{array}$ & \multicolumn{1}{c}{ Plastic Waste Type } & $\begin{array}{c}\text { Generation Amount of Each } \\
\text { Plastic Waste Type (kg/d) }\end{array}$ & Percentage (\%) \\
\hline 1-PET & Bottle (beverage, sauce, soy sauce, cooking oil) & 40,515 & 23.17 \\
2-HDPE & Bottle (shampoo, liquid soap, cosmetics, oil) & 6,991 & 9.93 \\
& Stationary (ballpoint, marker, ruler, correction tape, etc.) & 9,187 & 1.69 \\
& Bucket (soap dispenser, bucket, tub, washbasin, etc.) & 1,191 & 9.27 \\
3-PVC & Pipe & 1,076 & 9.94 \\
& Cable & 1,884 & \\
4-LDPE & Single-use plastic bags & 16,223 & \\
5-PP & Mineral water/beverages & 6,990 & 1.027 \\
& Food container & 517 & 4.85 \\
& Blister & 8,187 & 4.13 \\
& Cap bottle & 664 & 3,241 \\
6-PS & Bottle (medicine, baby's beverage) & 69,940 & 1,101 \\
7-Others & Styrofoam (food container, cup, etc.) & 665 & \\
& Plastic packaging & 5,451 & \\
& Toys & & \\
\hline
\end{tabular}

The total composition of municipal solid waste in Semarang City is approximately $179,800 \mathrm{~kg} /$ day or $21.52 \%$ of the complete solid waste in Semarang city. Urban waste is generally dominated by $51.9 \%$ of organic waste. According to a case study in Bandung City, inorganic waste consists of several types of waste with different percentages such as plastic at $15.70 \%$, $0.70 \%$ glass, $9.34 \%$ paper, $3.90 \%$ fabric, $0.60 \%$ rubber, metal $0.30 \%$ with total daily waste production reaching 1,500 tons/day (Damanhuri et al., 2009). Based on the recycling code, plastic waste is divided into seven types of waste which include; PET (Polyethylene Terephthalate), HDPE (High-Density Polyethylene), PVC (Poly Vinyl Chloride), LDPE (LowDensity Polyethylene), PP (Polypropylene), PS (Polystyrene), and others.

Based on Table 2, it can be seen that the most significant plastic waste is other types of waste $(44.13 \%)$. The different types of waste consist of plastic packaging, children's toys, electronic devices, and household appliances. Products that use plastic packaging such as snack packs, sweets, detergents, 
shampoos, and so on were pretty much found. The composition of the smallest plastic waste is polystyrene or PS (1.85\%). This type of PS waste was found in a variety of styrofoam products, both food containers and items that use styrofoam. PS waste generation was only a few because the use of styrofoam in daily activities tends to be small, so the amount is not as significant as other types of waste. Sources that plastic waste generated from varied at each level of the recycling agents in Semarang City.

Table 3 shows the average amount and weight of plastic waste collected at each level of the recycling agents based on field surveys in Semarang City. The importance of plastic waste that can be recovered for each actor is different. On average, all actors except the intermediates are more likely to improve waste PET bottles and HDPE buckets because of the high selling price of each type of waste. Single-use plastic bags, plastic packaging, and stationery seem to have no sale value, so they have no chance of recovery. Nevertheless, the amount of solid waste generated by these three types of waste is large enough so that special handling is needed.

Table 3. Plastic waste managed by each level of recycling agents

\begin{tabular}{|c|c|c|c|c|c|c|}
\hline \multirow{2}{*}{$\begin{array}{l}\text { Recycling } \\
\text { code }\end{array}$} & \multirow[b]{2}{*}{ Waste Type } & \multicolumn{5}{|c|}{ Amount (kg/day) } \\
\hline & & Scavenger & $\begin{array}{l}\text { Scrap } \\
\text { dealer }\end{array}$ & $\begin{array}{c}\text { Small-scale } \\
\text { enterprise }\end{array}$ & $\begin{array}{c}\text { Large-scale } \\
\text { enterprise }\end{array}$ & Intermediates \\
\hline \multirow[t]{2}{*}{ 1-PET } & Beverage bottle & 6.00 & 13.55 & 85.11 & 518.40 & 250 \\
\hline & $\begin{array}{l}\text { Soy sauce and another sauce } \\
\text { bottle }\end{array}$ & 2.10 & 5.37 & 30.41 & 186.47 & 100 \\
\hline \multirow[t]{3}{*}{ 2-HDPE } & $\begin{array}{l}\text { Bottle (shampoo, soap, } \\
\text { cosmetics) }\end{array}$ & 2.40 & 6.14 & 43.3 & 178.73 & 100 \\
\hline & $\begin{array}{l}\text { Stationary (ballpoint, marker, } \\
\text { ruler, correction tape, etc.) }\end{array}$ & 0.00 & 0 & 0 & 0 & 0 \\
\hline & $\begin{array}{l}\text { Bucket (soap dispenser, } \\
\text { bucket, tub, washbasin, etc.) }\end{array}$ & 2.80 & 8.15 & 60.795 & 303.70 & 250 \\
\hline \multirow[t]{2}{*}{ 3-PVC } & Pipe & 1.00 & 1.54 & 12.95 & 55.87 & 30 \\
\hline & Cable & 0.67 & 0.60 & 8.27 & 5.67 & 15 \\
\hline 4-LDPE & $\begin{array}{l}\text { Single-use plastic bags and } \\
\text { the like }\end{array}$ & 0.00 & 0 & 0 & 0 & 0 \\
\hline \multirow[t]{5}{*}{ 5-PP } & Mineral water/beverages & 2.00 & 6.41 & 27.04 & 128.47 & 200 \\
\hline & Food container & 0.50 & 0.56 & 9.31 & 45.33 & 50 \\
\hline & blister & 0.00 & 0 & 0 & 0 & 0 \\
\hline & Cap bottle & 0.47 & 3.02 & 17.82 & 85.93 & 1,000 \\
\hline & $\begin{array}{l}\text { Bottle (medicine, baby's } \\
\text { beverage) }\end{array}$ & 0.88 & 1.45 & 13.53 & 77.03 & 50 \\
\hline 6-PS & $\begin{array}{l}\text { Styrofoam (food container, } \\
\text { cup, etc.) }\end{array}$ & 0.80 & 0.39 & 3.61 & 11.73 & 15 \\
\hline \multirow[t]{4}{*}{ 7-Others } & Plastic packaging & 0.00 & 0 & 0 & 0 & 0 \\
\hline & Toys & 1.40 & 1.95 & 8.395 & 50.30 & 35 \\
\hline & Electronics & 1.38 & 2.72 & 11.65 & 50.13 & 40 \\
\hline & $\begin{array}{l}\text { Household consumables } \\
\text { (toothbrush, etc.) }\end{array}$ & 1.60 & 2.89 & 15.3 & 37.53 & 25 \\
\hline \multicolumn{2}{|c|}{ Average Weight (kg/day) } & 23.98 & 23.98 & 347.48 & $1,735.30$ & 2,160 \\
\hline
\end{tabular}

\subsection{The Role of the Informal Sector in Plastic Waste Recycling}

\subsubsection{Scavenger}

Scavenger operation time has no standard in which they may operate all day. Scavengers work everywhere throughout the sub-districts in Semarang city and work door-to-door or settle in transfer depo or final disposal (landfill). They often search for recyclables to areas far from the sub-district where they live so that the number of scavengers is quite challenging to estimate (Sasaki et al., 2014). The average weight of plastic waste collected by scavengers was $23.98 \mathrm{~kg} /$ day. The types of plastic waste collected by scavengers were beverage bottles weighing $6 \mathrm{~kg} /$ day, while the least kind of plastic was bottle cap with a weight of $0.47 \mathrm{~kg} /$ day. The amount of plastic waste obtained by scavengers is the smallest amount of waste compared to other plastic waste recycling agents because the amount of waste collected by scavengers is limited depends on the availability or quantity of plastic waste in the area pass through. They may receive a much more 166 considerable amount during occasion events that have the potential to generate massive enough solid waste such as a wedding, parties, ceremony, etc.

According to Putri et al. (2018), plastic waste were recycled at the Final Disposal Site (TPA) through scavengers and waste banks. Scavengers collect plastic waste of $239 \mathrm{~kg} / \mathrm{month}$, and the waste bank can collect up to $260 \mathrm{~kg} / \mathrm{month}$. The amount of waste managed by scavengers and waste banks has no significant difference. Scavengers recycle approximately $24-29 \%$ of plastic waste from the total plastic waste generated whereas, about $71-76 \%$ of the remainder are disposed to landfills (Putri et al., 2018).

\subsubsection{Scrap Dealers}

The scrap builders (see Figure 2) in Semarang City in this study are categorized in the informal sector recycling business that receives plastic waste with a capacity of less than $100 \mathrm{~kg} /$ day. Based on a survey of 17 scrap dealers who sell plastic waste, the scrap dealer obtains the valuable economic waste from the community and scavengers and then sell it to 
a more extensive dealer. The average weight of plastic waste collected by scrap dealers in Semarang City was $54.74 \mathrm{~kg} /$ day. The most common type of plastic waste managed by scrap dealers was beverage bottles weighing $13.55 \mathrm{~kg} /$ day while the least kind of plastic was styrofoam with a weight of $0.39 \mathrm{~kg} /$ day. The operational activity carried out by a scrap dealer is sorting, because the waste received is still mixed. Sorting is done manually using human labor.

Scrap dealer is an informal sector recycling business that has a relatively small waste collection capacity. The scrap dealer takes the solid waste from the community on a door-to-door basis or buy it from scavengers and then sell it to recycling shops or smallscale enterprise. A small-scale enterprise usually employs a scrap dealer, or they form a community so that the collected recyclable can be increased. The scrap dealer acts as a waste sorter because picking up waste from house to house or buying to scavengers is often mixed into one. Waste sorting activities are carried out manually using human labor (Matter et al., 2013). Plastic waste collected by the scrap dealer can reach up to $280 \mathrm{~kg} /$ month.
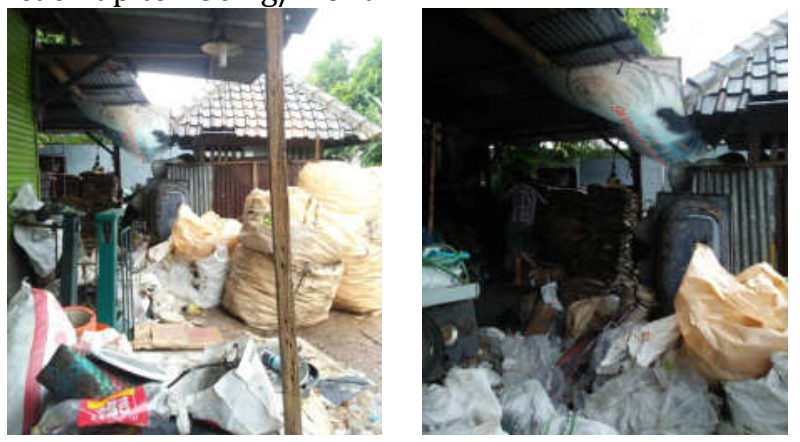

Figure 2. Scrap dealer

\subsubsection{Small-Scale Entreprises}

Small-scale enterprise located in Semarang City is categorized in an informal sector recycling business that receives plastic waste with a capacity of between $100-1,000 \mathrm{~kg}$. The condition of small-scale enterprise can be seen in Figure 3. The small dealer receives waste from the households, scavengers, and scrap dealers and then sells it to large-scale enterprise or plastic waste grinding mill (the intermediate). The average weight of plastic waste collected in Semarang City is about $347.48 \mathrm{~kg} /$ day. Similar to previous recycling agents, the most common type of plastic waste managed by the city is beverage bottles weighing $85.11 \mathrm{~kg} /$ day, whereas styrofoam is the least with a weight of $3.61 \mathrm{~kg} /$ day. Operational activities carried out in small-scale enterprises are a validation of the tonnage of waste from consumers and sorting, because the waste received is still in mixed condition. The small-scale enterprise does not have waste treatment equipment. Hence, waste sorting is done manually using human labor. The sorted waste will be sold to the intermediate using a pick-up truck.

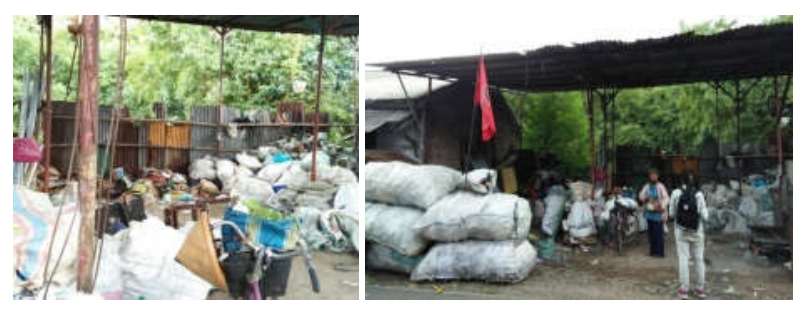

Figure 3. Small-scale enterprise

\subsubsection{Large-scale Entreprises}

Large-scale enterprise is a recycling business that receives plastic waste with a capacity of more than $1,000 \mathrm{~kg}$. The Large-scale enterprise obtained the solid waste from the scrap dealer and small-scale enterprises. Still, some receive it from individuals, as well as scrap dealers, and then sell it to the plastic waste grinder and processing factory outside Semarang City. The difference between small and large-scale entreprises is the capacity of plastic waste managed every day. The large-scale enterprise has a large warehouse capacity so that it can collect more than 1 ton of waste and have more customers. The average weight of plastic waste collected by the largescale enterprise is $1,735.3 \mathrm{~kg} /$ day. The most common type of plastic waste managed by the large-scale enterprise is beverage bottles weighing $518.4 \mathrm{~kg} /$ day. While the least kind of plastic is styrofoam with a weight of $11.73 \mathrm{~kg} /$ day. Operational activities carried out in large-scale enterprises are sorting and pressing. Most of the plastic waste received by the city is already classified according to each type of waste (usually not an only plastic waste but also other recyclables). However, there is also waste that is still mixed so that it needs reprocessing. The chemical waste processing equipment owned by large-scale enterprises is only a pressing machine to reduce the volume of waste. The output of plastic waste treated by the large-scale enterprise must be sorted and compacted, so it is ready to be further processed by the grinding mill (the intermediate) and factory (waste plastic recycling industry to produce recycled plastic ore).
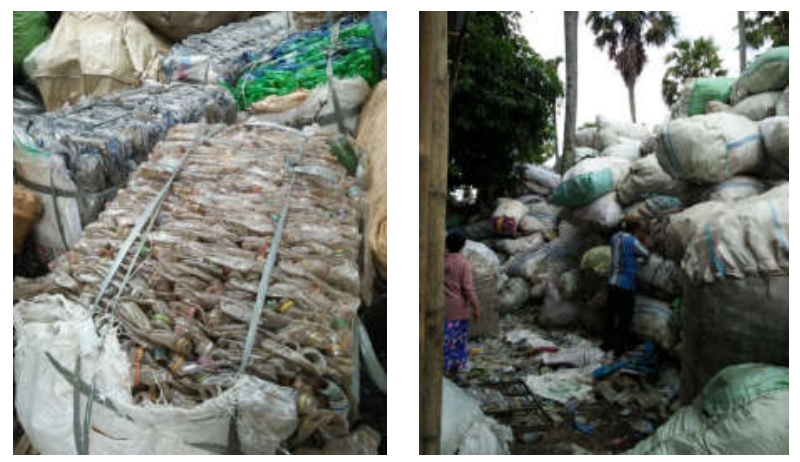

Figure 4. Large-scale enterprise

\subsubsection{Intermediates}

The grinding mill is a recycling agent that processes certain types of plastic waste using a grinding machine. Figure 5 shows the condition of this mill and plastic ore produced by grinding mills. They 
provide plastic ore in the same size of plastic waste. The intermediate receives plastic waste from the small and large-scale enterprise. They do not process the plastic ore to become a recycled plastic so that the grinding mill can be referred to as intermediate. The average weight of plastic waste treated by the grinding mill is $2,160 \mathrm{~kg} /$ day. The most common type of plastic waste managed by the intermediate was 18 $\mathrm{L}$ mineral water container (usually referred to as "gallon" in Bahasa) caps with a weight of up to 1,000 $\mathrm{kg} /$ day. Meanwhile, the least types of plastic found were styrofoam and cable weighing $15 \mathrm{~kg} /$ day.

The operational activity carried out by the intermediate is processing using a plastic chopper machine with the results of a mill in the form of chopped plastic, which will later be transformed into plastic ore by industries located outside Semarang City. A grinding machine is a machine equipped with a knife that is rotated by a motor. The process of grinding plastic waste can be done by wet and dry grinding. Wet grinding requires water as a washing media so that the selling price will be higher than dry grinding. Based on the surveys and interviews with the intermediate, the type of waste that has the highest economic value is the gallon cap, because the selling price is quite high and relatively stable, and the shrinkage (lost material) is the smallest compared to other types of plastic waste when processed. The type of plastic cup packaging has the highest decrease when processed using a grinding machine. When processing plastic waste using a grinding machine, there is a shrinkage (lost material) in the range of $5 \%$ - $20 \%$. Therefore, the weight of the ground plastic produced will reduce compared to the initial load.
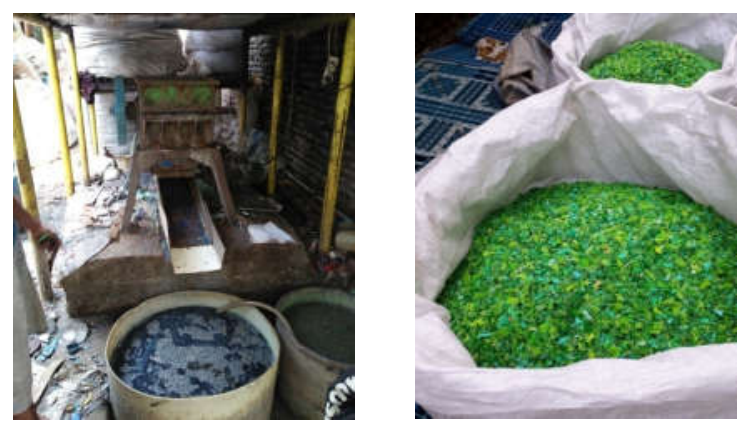

Figure 5. Plastic waste grinding mill (intermediate)

Table 4. Summary of recycling agent characteristics

\begin{tabular}{|c|c|c|c|c|c|}
\hline Differentiate & Scavenger & Scrap dealer & $\begin{array}{l}\text { Small-scale } \\
\text { enterprise }\end{array}$ & $\begin{array}{c}\text { Large-scale } \\
\text { enterprise }\end{array}$ & Intermediates \\
\hline Recycling capacity & $<100 \mathrm{~kg} /$ day & $<100 \mathrm{~kg} /$ day & $100-1.000 \mathrm{~kg} /$ day & $>1.000 \mathrm{~kg} /$ day & $>1,000 \mathrm{~kg} /$ day \\
\hline Operation time & No working hour & Working hour & Working hour & Working hour & Working hour \\
\hline $\begin{array}{l}\text { Average weight of } \\
\text { plastic recycling }\end{array}$ & $23.98 \mathrm{~kg} /$ day & $54,74 \mathrm{~kg} /$ day & 347,48 kg.day & $1,735.3 \mathrm{~kg} /$ day & $2,160 \mathrm{~kg} /$ day \\
\hline $\begin{array}{l}\text { The most type of } \\
\text { plastic that is } \\
\text { recycled }\end{array}$ & Beverage bottles & Beverage bottles & Beverage bottles & Beverage bottles & $\begin{array}{l}18 \mathrm{~L} \text { mineral water } \\
\text { container }\end{array}$ \\
\hline $\begin{array}{l}\text { The least type of } \\
\text { plastic that is } \\
\text { recycled }\end{array}$ & Bottle cap & Styrofoam & Styrofoam & Styrofoam & $\begin{array}{l}\text { Styrofoam and } \\
\text { cable }\end{array}$ \\
\hline Main activities & $\begin{array}{l}\text { Plastic collection } \\
\text { from the sources, } \\
\text { selling the plastic to } \\
\text { scrap dealer }\end{array}$ & $\begin{array}{l}\text { Waste sorting, } \\
\text { Selling the plastic to } \\
\text { enterprise }\end{array}$ & $\begin{array}{l}\text { Waste sorting, } \\
\text { Selling the plastic to } \\
\text { intermediates or } \\
\text { other enterprise }\end{array}$ & $\begin{array}{l}\text { Waste sorting and } \\
\text { compaction, Selling } \\
\text { the plastic to } \\
\text { intermediates or } \\
\text { other enterprise }\end{array}$ & $\begin{array}{l}\text { Grinding the plastic, } \\
\text { collecting, selling } \\
\text { the plastic to } \\
\text { manufactures }\end{array}$ \\
\hline
\end{tabular}

\subsubsection{Discussion}

Municipal solid waste management in developing countries is divided into two, namely formal and informal. Formal waste management is waste management carried out by the government. The formal waste management process involves collecting waste from a predetermined collection point then transporting to the landfill periodically at a particular time. Officers further sort of solid waste reached in the landfill. Recyclable waste is then separated from non-recyclable waste. Meanwhile, informal waste management is proper waste management outside of government intervention. Actors of this informal waste activity are scavengers, scrap dealers, small-scale enterprises, large-scale enterprises, grinders and manufactures. Each region has a collection system that ends up producing recycled plastic ore (Makarichi et al., 2018).

The informal waste management system in Indonesia generally has a pyramid-like policy where each intermediate (grinding mill) obtains raw material (plastic waste) from several large-scale enterprises. Each of the large-scale enterprises is in charge of several small-scale enterprises. They get their raw materials from scavengers and flea workers who are employed or individuals. Each stage of informal waste management (See Table 4) has its operational activities such as the sorting process that occurs at the level of the scrap dealers, the process of collecting at the large-scale entreprises, and the treatment process (grinding) at the intermediate (grinding mill). The collection process is carried out by scavengers (waste pickers) and scrap dealers (Sasaki et al., 2014).

\section{Conclusion}

Plastic waste in Semarang City, as an input, comes from the household (domestic) and other public facilities (non-domestic sources). Meanwhile, the final destination (as output) of the plastic waste generated consists of ground plastic waste in Semarang City. The further plastic waste processing 
plant was located outside Semarang City. The flow of plastic waste recycling by the informal sector starts at the level of scavengers, scrap dealers, small-scale enterprise, large-scale enterprise, and intermediate. However, this flow is not standard, meaning that scavengers or scrap dealers can directly sell recyclable waste to small/large enterprises with the minimum weight requirement met. The plastic waste can later be processed further into the same products. It can also be used as primary or secondary raw materials for manufacturing other products.

The amount of plastic waste generated by each recycling agents is estimated at $23.98 \mathrm{~kg} /$ day at the scavenger level, $54.74 \mathrm{~kg} /$ day at the scrap dealer level, $347.48 \mathrm{~kg} /$ day at the small-scale enterprise level, $1,735.3 \mathrm{~kg} /$ day at the large-scale enterprise level, and $2,160 \mathrm{~kg} /$ day at the level of intermediate. Semarang City has the economic potential of recycling plastic waste for the informal sector. Each recycling market participant from scavengers, scrap dealers, to intermediate has different levels of buying and selling prices. The price level starting from the lowest price to the highest price are scavengers, scrap dealers, small-scale enterprises, large-scale enterprise, and intermediate, respectively

\section{Acknowledgment}

The authors would like to acknowledge Research and Community Services (LPPM), Universitas Diponegoro, that financially supporting the research under Riset Pengembangan dan Penerapan (RPP) scheme Number 329 - 128/UN7.P4.3/PP/2019.

\section{REFERENCES}

Aprilia, A., Tezuka, T., Spaargaren, G. 2013. Inorganic and hazardous solid waste management: Current status and challenges for Indonesia. Procedia Environmental Sciences 17 , https://doi.org/10.1016/j.proenv.2013.02.080

Aye, L., Widjaya, E.R., 2006. Environmental and economic analyses of waste disposal options for traditional markets in Indonesia 26, 1180-1191. https://doi.org/10.1016/j.wasman.2005.09.010

Batool, S.A., Chaudhry, N., Majeed, K., 2008. Economic potential of recycling business in Lahore, Pakistan. Waste Manag. 28, 294-298. https://doi.org/10.1016/j.wasman.2006.12.007

Budihardjo, M.A., Wahyuningrum, I.F.S., 2018. Recovery Practice of Unsorted Solid Waste: From Landfill towards Economic Benefits in Semarang, Indonesia. MATEC Web Conf. 159, 0-4. https://doi.org/10.1051/matecconf/201815901029

Chaerul, M., Fahrurojo, A.R., Fujiwara, T. Recycling of plastic packaging waste in Bandung City, Indonesia. J. Mater. Cycles Waste Manag. 16, 509-518. https://doi.org/10.1007/s10163-013-0201-2

Damanhuri, E., Wahyu, I.M., Ramang, R., Padmi, T., 2009. Evaluation of municipal solid waste flow in the Bandung metropolitan area, Indonesia. J. Mater. Cycles Waste Manag. 11, 270-276. https://doi.org/10.1007/s10163-009-0241-9

Filho, W.L., Saari, U., Fedoruk, M., Iital, A., Moora, H., Klöga, M., Voronova, V., 2019. An overview of the problems posed by plastic products and the role of extended producer responsibility in Europe. J. Clean. Prod. 214, 550-558.

https://doi.org/10.1016/j.jclepro.2018.12.256

Govindan, K., Soleimani, H., Kannan, D., 2015. Reverse logistics and closed-loop supply chain: A comprehensive review to explore the future. Eur. J. Oper. Res. 240, 603-626. https://doi.org/10.1016/j.ejor.2014.07.012

Gregory, J.R., Kirchain, R.E., 2008. A framework for evaluating the economic performance of recycling systems: A case study of North American electronics recycling systems. Environ. Sci. Technol. 42, 68006808. https://doi.org/10.1021/es702666v

Herewila, K., Ramang, R., Henuk, Y.L., 2017. The Role of the Scavengers in Orders to Reduce Plastic Waste In Alak Landfill Sites Of Kupang City 11, 61-64. https://doi.org/10.9790/2402-1110026164

Kinobe, J.R., Gebresenbet, G., Niwagaba, C.B., Vinnerås, B., 2015. Reverse logistics system and recycling potential at a landfill: A case study from Kampala City. Waste Manag. 42, 82-92. https://doi.org/10.1016/j.wasman.2015.04.012

Lemieux, P.M., Lutes, C.C., Abbott, J.A., Aldous, K.M., 2000. Emissions of polychlorinated dibenzo-p-dioxins and polychlorinated dibenzofurans from the open burning of household waste in barrels. Environ. Sci. Technol. 34, 377-384. https://doi.org/10.1021/es990465t

Lestari, P., Trihadiningrum, Y., 2019. The impact of improper solid waste management to plastic pollution in Indonesian coast and marine environment. Mar. $\begin{array}{llll}\text { Pollut. Bull. } & 110505 .\end{array}$ https://doi.org/10.1016/j.marpolbul.2019.110505

Makarichi, L., Techato, K. anan, Jutidamrongphan, W., 2018. Material flow analysis as a support tool for multicriteria analysis in solid waste management decisionmaking. Resour. Conserv. Recycl. 139, 351-365. https://doi.org/10.1016/j.resconrec.2018.07.024

Matter, A., Dietschi, M., Zurbrügg, C., 2013. Improving the informal recycling sector through segregation of waste in the household - The case of Dhaka Bangladesh. Habitat Int. 38, 150-156. https://doi.org/10.1016/j.habitatint.2012.06.001

Nahman, A., 2010. Extended producer responsibility for packaging waste in South Africa: Current approaches and lessons learned. Resour. Conserv. Recycl. 54, 155-162.

https://doi.org/10.1016/j.resconrec.2009.07.006

Pertiwi, A., Kiky, S.M.P., Wiwik, B., Ratna, P., Budi, P.S., Arya, R., 2018. Preliminary Study on Plastic Waste Handling in Semarang City - Indonesia: Estimated Generation and Existing Management. E3S Web Conf. 73. https://doi.org/10.1051/e3sconf/20187307008

Putri, A.R., Fujimori, T., Takaoka, M., 2018. Plastic waste management in Jakarta, Indonesia: evaluation of material flow and recycling scheme. J. Mater. Cycles Waste Manag. 20, 2140-2149. https://doi.org/10.1007/s10163-018-0753-2

Sasaki, S., Araki, T., Halomoan, A., Prasadja, H., Tambunan, A.H., Prasadja, H., 2014. Household income, living and working conditions of dumpsite waste pickers in Bantar Gebang: Toward integrated waste management in Indonesia. Resour. Conserv. Recycl. 89,

11-21. https://doi.org/10.1016/j.resconrec.2014.05.006

Thompson, R.C., 2006. Plastic debris in the marine 
environment: consequences and solutions, in: Krause, J.C., Nordheim, H. von, Bräger, S. (Eds.), Marine Nature Conservation in the Europe. Bundesamt für Naturschutz (BfN), Bonn, Germany.

Tong, X., Wang, T., Chen, Y., Wang, Y., 2018. Towards an inclusive circular economy: Quantifying the spatial flows of e-waste through the informal sector in China. Resour. Conserv. Recycl. 135, 163-171. https://doi.org/10.1016/j.resconrec.2017.10.039

Xu, Z., Elomri, A., Pokharel, S., Zhang, Q., Ming, X.G., Liu, W., 2017. Global reverse supply chain design for solid waste recycling under uncertainties and carbon emission constraint. Waste Manag. 64, 358-370. https://doi.org/10.1016/j.wasman.2017.02.024
Yukalang, N., Clarke, B., Ross, K., 2017. Barriers to Effective Municipal Solid Waste Management in a Rapidly Urbanizing Area in Thailand. Int. J. Environ. Res. Public Health 14, 1-23. https://doi.org/https://doi.org/10.3390/ijerph1409 1013

Yuliastuti, N., Saraswati, N., 2014. Environmental Quality in Urban Settlement: The Role of Local Community Association in East Semarang Sub-District. Procedia Soc. Behav. Sci. 135, 31-35. https://doi.org/10.1016/j.sbspro.2014.07.321 